\title{
UK geographers vote to cut links with Shell
}

London. Members of Britain's Royal Geographical Society (RGS) have voted in favour of dropping the Shell oil company as one of the society's four corporate patrons in protest at the multinational's environmental record in Nigeria. The size of the vote - 204 in favour, with 10 against — has led to calls for the RGS's ruling council to sever the society's links with Shell immediately.

David Gilbert, a lecturer in geography at Royal Holloway College, University of London, who moved the motion during a meeting at the annual conference of the society last week, said in a statement that Shell's environmental and political record in Nigeria "makes the company unfit to be patron of any society representing practising geographers". A spokesman for the company responded by saying that it would be "sad" if the link were severed.

Shell has been heavily criticized for failing to intervene to stop the execution by the Nigerian government last November of Ken Saro-Wiwa and eight other activists belonging to the Movement for the Survival of the Ogoni People (MOSOP). MOSOP claims that oil exploration and drilling from Shell installations in the Ogoni region has devastated the local environment, and that the Ogoni people have been denied their share of the wealth generated by the oil industry.

Gilbert says the RGS's link with Shell compromises the integrity of academic studies of the Ogoni issue, and claims that "Shell is attempting to buy legitimacy in these areas through its patronage of the society".

The charges are denied by Shell. While admitting the existence of "environmental problems" in the area, company officials say they cannot become involved in the domestic politics of a sovereign state. The company also says that it contributed $\$ 25$ million towards environmental and community projects in Nigeria last year.

Eric Nickson, a spokesman for Shell International, adds that Shell spent more than $£ 10$ million on conservation, environ-

(from page 103) from Crozemarie. Responding to public statements by Crozemarie that he would dissolve the charity rather than resign, the working group last weekend reminded him that such a step would require approval of ARC's general assembly. "It is divorce," said one board member.

According to an official present at the emergency meeting, most board members also opposed keeping Crozemarie as chairman of the charity. The only reason Crozemarie was not asked to resign immediately, he says, is that the board wanted time to find an "irreproachable" successor, such as a retired judge or a leading scientist from a field other than cancer research. ment and development last year. The company's $£ 40,000(\$ 60,000)$ annual grant to the RGS, he says, helps to fund the Expedition Advisory Centre, "an effective means to help young people to take an interest in environmental development issues".

The vote, which was taken on 5 January at an open meeting at the RGS conference at the University of Strathclyde, Scotland, has no constitutional status within the RGS.

\section{IMAGE UNAVAILABLE FOR COPYRIGHT REASONS}

Saro-Wiwa: execution prompted protests.

But the strength of feeling among members at the meeting has prompted the society's governing body to take steps to address the issues raised.

The implications of corporate patronage for a learned society will be the subject of an internal review chaired by Sir Crispin Tickell, a vice president of the RGS and Warden of Green College, Oxford. The names of the society's four corporate patrons - which also include British Airways, Land Rover, and Hong Kong and Shanghai Bank Holdings - appear on the society's stationery.

Meanwhile, the question of the environmental impact of multinational corporations working in the developing world is to be considered at a special RGS symposium later in the year.

According to Tim Unwin, honorary secretary of the RGS and reader in geography at Royal Holloway College, University of London, both steps have been taken in order to show that "a major learned

The working group admits that its aim is to re-establish public confidence in ARC and ensure the charity's survival. This goal is shared by many researchers who argue that funding from charities is essential to the livelihood of their laboratories. Most public funding goes on salaries and overheads, and private income provides much needed funds for equipment and supplies.

Other researchers argue, however, that the ARC affair reveals that the influence of charities is disproportionate compared with the state's total spending on biomedical research, and carries the risk of concentrating control over research excessively in the hands of a few powerful individuals.

Declan Butler society can be completely open about a controversial subject and move forward in a positive way".

Despite last week's vote and the impending sponsorship review, some observers believe that the 166-year-old RGS is unlikely to make major changes in its present policy of actively encouraging government and industrial sponsorship for its activities, particularly its showpiece multidisciplinary expeditions overseas.

The RGS's political and industrial connections, as well as its access to many diverse sources of funding, are envied by many organizations. Indeed, this is believed to a key factor behind a vote last year by members of the more academic but relatively impoverished Institute of British Geographers to rejoin the RGS after breaking away in 1933.

Other learned bodies, such as the Royal Society and the Institute of Physics, also maintain links with industry - but have no tradition of corporate patronage. The oil company Esso sponsors an award and a medal in conjunction with the Royal Society. The 21,000-member Institute of Physics (IOP) operates a scheme in which commercial organizations can become 'corporate affiliates' by paying $£ 2,000$.

Asked if the IOP would consider an application for affiliation from Shell, Susan Partridge, industrial affairs manager at the IOP, says such a request would not be automatically ruled out. "Affiliates are not screened on commercial criteria, as that would exclude important branches of physics," she says. "Physics comes first."

Environmentalist organizations have also found ways to harness corporate support. Ten per cent ( $£ 2$ million) of the income for the World Wide Fund for Nature (WWF), for example, comes from corporate activity, including a scheme in which the WWF licenses its panda logo for products that are produced using eco-friendly methods.

WWF has also accepted both unsolicited as well as project-oriented donations, known as Corporate Partnerships, from Shell. The former includes a sum of $£ 9,600$ received between 1992 and 1995. A Shell-supported project on wildlife habitat and forestry plantations is an example of the latter.

Robin Pellew, chief executive of WWF, says candidates for Corporate Partnerships are screened for ethical and environmental credibility. "WWF did not know of Shell's activities in Nigeria" when the company was last approached. WWF, he adds would not approach Shell in the future, but would not turn down unsolicited donations

A spokesman for Shell, however, says that its $£ 9,600$ donation to WWF was not unsolicited. "A number of ideas were circulated by WWF and we made a donation to one of them."

Ehsan Masood 